\title{
PERGERAKAN BERSAMA INDEKS PASAR SAHAM SYARIAH DAN VARIABEL MAKRO EKONOMI: Pendekatan Regime-Switching Regression
}

\section{Buddi Wibowo}

Fakultas Ekonomi dan Bisnis, Universitas Indonesia

E-mail: buddi.wibowo@ui.ac.id, buddi.wibowo@ui.ac.id

\section{Abstrak}

Pergerakan bersama (comovement) antara indeks syariah dengan variabel makro ekonomi khususnya suku bunga menimbulkan beberapa pertanyaan teoritis dan empiric sekaligus. Signifikannya hubungan antara imbal hasil indeks syariah di Bursa Efek Indonesia dengan perubahan suku bunga memunculkan pertanyaan apakah saham-saham perusahaan yang termasuk di dalam Jakarta Islamic Index telah disaring secara ketat sehingga komponen biaya bunga sudah minimal atau karena mikro struktur pasar saham Indonesia yang didominasi investor asing. Pola comovement antara indeks syariah dengan indeks pasar konvensional dan nilai tukar patut diduga sangat dipengaruhi oleh volatilitas suku bunga yang sedang berlangsung. Pengukuran comovement membutuhkan model 
yang mampu menunjukkan pola tersebut secara robust. Model regresi Markov regime-Switching mengungkapkan adanya perbedaan signfikan pengaruh perubahan nilai tukar terhadap imbal hasil indeks syariah antara regime volatilitas yang tinggi dengan regime volatilitas yang rendah. Pengaruh nilai tukar hanya signifikan pada saat regime volatilitas yang rendah. Hal ini tidak dapat diungkap jika kita hanya menggunakan model regresi linier OLS biasa.

Kata Kunci: Indeks Syariah, Suku Bunga, Nilai Tukar, Regime Switching

\section{Abstract}

Relationship between syariah index with macroeconomic variables is a research topics that attracts the attention of many researchers. Comovement between syariah index with a conventional stock market index indicates a cointegration relationship between both markets. Comovement between syariah index and conventional market index is much stronger at the time of low volatility compared to the high volatility regime. The significant relationship between Shariah index yield in Indonesia Stock Exchange with changes and interest rates raises the question of whether all stocks which are included in the Jakarta Islamic Index has adequately filtered so that the components of interest expense is minimal or because the microstructure Indonesian stock market which is dominated by foreign investor. Markov regime-switching model reveals the existence of significant differences effects of exchange rates on the shariah index in high volatility and low volatility regime. Effect of exchange rates is significant only at the time of low volatility regime. This phenomenon cannot be revealed if we use the usual OLS linear regression model, instead of Markov regimeSwitching regression model.

KeyWords: Shariah Index, Interest rate, Exchange Rate, Regime Switching 


\section{PENDAHULUAN}

Pasar saham suatu negara sangat ditentukan oleh kondisi makro ekonomi negara tersebut. Banyak peneliti telah mengungkapkan hasil uji empiris atas hipotesis klasik tersebut dengan berbagai hasil yang sebagian saling bertentangan. Fama (1981) dan Geske and Roll (1983), misalnya, menemukan ekspektasi inflasi berhubungan negatif dengan imbal hasil pasar saham. Inflasi mencerminkan risiko keuangan di masa depan sehingga membuat nilai intrinsik saham menjadi terdiskon lebih besar. Sementara, kelompok peneliti yang lain seperti Choudhry, (2001); Hondroyiannis \& Papapetrou, menemukan fakta sebaliknya yaitu (2006) memiliki hubungan positif dengan imbal hasil indeks bursa saham. Ekspektasi inflasi menunjukkan keyakinan investor terhadap aktivitas ekonomi di masa depan yang diduga akan mempengaruhi langsung kinerja perusahaanperusahaan di masa depan sehingga harga saham secara rata-rata mengalami kenaikan sejak periode sekarang.

Uji empiris hubungan antara tingkat suku bunga dengan indeks harga saham juga menghasilkan mixed result. Pandangan klasik mempercayai bahwa kenaikan sukubungaakanmenyebabkan meningkatnya opportunity cost untuk memegang uang kas serta membuat investasi di dalam interest bearing securities menjadi semakin menarik dibandingkan saham. Teori keuangan klasik menyatakan hubungan antara harga saham dan suku bunga bersifat negatif karena harga saham saat ini adalah hasil dari discounted future cash flow dimana nilai intrinsik sekarang suatu saham dihitung dengan cara mendiskon arus kas masa depan dengan suatu discount rate yang mencerminkan tingkat risiko untuk dapat diperolehnya arus kas tersebut. Semakin tinggi discount rate menyebabkan semakin rendah nilai sekarang suatu saham sehingga menyebabkan munculnya tekanan jual dan menurunnya harga saham tersebut di pasar. Salah satu faktor utama yang mempengaruhi discount rate tersebut adalah tingkat suku bunga. Beberapa riset klasik membuktikan adanya hubungan negatif antara harga saham dan suku bunga jangka pendek (Chen, 
Roll, \& Ross, 1986; Shiller \& Beltratti, 1992). Rigobon and Sack (2004) membuktikan hal yang sebaliknya dari pandangan klasik tersebut, mereka justru menemukan bahwa perubahan suku bunga secara searah mempengaruhi pergerakan harga di pasar saham. Suku bunga bergerak searah dengan pergerakan indeks harga saham.

\section{Hubungan}

variabel makro ekonomi dengan indeks harga saham memiliki karakteristik yang berbeda pada konteks indeks harga saham syariah dimana saham-saham yang termasuk dalam pembentuk indeks harga saham syariah adalah saham-saham dari perusahaan yang memiliki keterkaitan dengan suku bunga yang minimal. Saham perusahaan yang dapat dimasukkan ke dalam suatu indeks harga saham syariah adalah saham dari perusahaan yang memiliki kewajiban pembayaran suku bunga yang sangat rendah dan, tentu saja, memiliki aktivitas bisnis yang tidak melanggar prinsip-prinsip syariah. Jakarta Islamic Index adalah indeks yang berisi 30 saham yang dipilih dari saham-saham yang masuk dalam kriteria syariah yaitu Daftar Efek Syariah yang diterbitkan oleh Otoritas Jasa Keuangan Republik Indonesia serta dengan mempertimbangkan perkembangan kapitalisasi pasar dan likuiditas setiap saham.

Isu penelitian hubungan antara variabel makroekonomi dan indeks pasar saham syariah mengalami komplikasi dengan adanya hubungan kointegrasi antara indeks pasar saham syariah dengan indeks pasar saham konvensional. Pertanyaan penelitian yang muncul adalah apakah pergerakan pasar saham syariah searah (comovement) dengan pergerakan pasar saham konvensional dan apakah terjadi perambatan volatilitas (volatility spillover) antara kedua pasar dan bagaimana kecenderungan arah perambatan volatilitas tersebut.

\section{Beberapa}

studi terbaru keuangan Islam telah mengungkapkan uji empiris hubungan antara pasar keuangan Islam dan ekonomi makro serta hubungan antara pasar saham Islam dan pasar saham konvensional. Mohamad Yusof dan Abdul Majid (2007), misalnya, mempelajari hubungan antara volatilitas kebijakan moneter dan volatilitas pengembalian saham di pasar saham 
konvensional dan syariah di Malaysia selama periode dari Januari 1992 sampai Desember 2000. Mereka menunjukkan bahwa volatilitas tingkat bunga mempengaruhi volatilitas imbal hasil pasar saham konvensional tetapi tidak memiliki pengaruh cukup signifikan pada imbal hasil pasar saham Islam. Mereka menemukan untuk indeks pasar saham syariah, nilai tukar adalah indikator terpenting dari ketidakstabilan ekonomi yang mempengaruhi imbal hasil indeks pasar saham syariah. Menggunakan model GARCH, Albaity (2011) menyelidiki efek dari kebijakan moneter, suku bunga dantingkat inflasi pada indeks pasar saham syariah di Malaysia (Indeks Syariah Kuala Lumpur) dan Amerika Serikat (DowJones Islamic Market Index) selama periode dari bulan April 1999 sampai Desember 2007. Ia menemukan bahwa dalam model univariat, varians dari dua indeks dipengaruhi oleh pasokan uang (M2 dan M3) dan tingkat inflasi. Pada model multivariat, Dow Jones Islamic market Index dipengaruhi oleh suku bunga dan tingkat inflasi, baik pada persamaan mean maupun persamaan varians.

Abdul Majid dan Mohd.
Yusof (2009) menggunakan model autoregressive distributed lag untuk mengeksplorasi sejauh mana variabel ekonomi makro seperti indeks produksi industri, pasokan uang, nilai tukar riil efektif, dan tingkat bunga mempengaruhi perilaku indeks pasar saham syariah di Malaysia pada periode krisis keuangan pasca 1997. Mereka menemukan bahwa, kecuali untuk indeks produksi industri, semua variabel ekonomi makro yang dianalisis memiliki dampak yang signifikan terhadap imbal hasil pasar saham syariah. Shamsuddin (2014) mempelajari sensitivitas portofolio saham syariah Dow Jones selama periode dari 5 Januari 1996 sampai 8 April2011 dan dia berhasil mengungkapkan bahwa portofolio agregat saham syariah kebal terhadap risiko suku bunga. Namun, di tingkat sektoral beberapa portofolio ekuitas Islam menunjukkan paparan risiko tingkat bunga yang signifikan. Hussin, Muhammad, Abu Hussin, dan Abdul Razak (2012) menggunakan vektor autoregresi (VAR) untuk memeriksa hubungan antara nilai tukar, harga minyak, dan pasar modal syariah di Malaysia selama periode 
Januari 2007 sampai Desember 2011. Mereka menemukan bahwa indeks pasar saham syariah memiliki korelasi positif dan signifikan dengan harga minyak, tetapi mereka memiliki hubungan negatif dan tidak signifikan dengan kurs Ringgit Malaysia terhadap dolar AS. Selanjutnya, dalam jangka pendek, hanya variabel harga minyak yang mempengaruhi imbal hasil saham Islam; ini membuktikan bahwa harga minyakdapat memprediksi jangka pendek return saham syariah.

Sakti dan Harun (2013) menggunakan teknik time series kointegrasidan VAR untuk menganalisis jangka pendek dan jangka panjang hubunganantara Bursa Efek Jakarta Islamic Index dan variabel ekonomi makro; yaitu nilai tukar, tingkat inflasi, dan jumlah uang beredar dari tahun 2000 sampai 2010. Mereka membuktikan bahwa ada hubungan co-integration antara indeks harga saham syariah dan semua variabel makroekonomi.Albaity dan Ahmad (2008) menggunakan uji kausalitas dan uji kontegrasi Johansen untuk menguji hubungan jangka pendek dan jangka panjang antara Indeks Syariah Kuala Lumpur(KLSI) dan Indeks
Komposit Kuala Lumpur (KLCI) selama periode 19992005. Mereka menemukan bahwa dalam jangka pendek, diukur dengan tes bivariat Granger, terdapat kausalitas dua arah antara dua indeks itu. Hal ini berarti bahwa dalam jangka pendek baik kedua indeks harga bergerak ke arah yang sama dan cenderung saling mempengaruhi satu sama lain. Sementara itu, untuk hubungan jangka panjang, KLCI menyesuaikan diri dengan cepat ke ekuilibrium jangka panjangnya sementara KLSI tidak. Ajmi et al (2014) menggunakan heteroskedasticity-robust linear Granger causality dan tes kausalitas linier Granger untuk menguji hubungan antara imbal hasil indeks pasar saham konvensional global dan pasar saham Islam serta antara pasar saham Islam dan beberapa guncangan ekonomi dan keuangan global selama periode 4 Januari 1999 sampai 8 Oktober 2010. Mereka mengungkapkan adanya hubungan signifikan linear dan kausalitas nonlinier antara pasar saham Mereka juga menunjukkan adanya hubungan signifikan antara pasar saham Islam dan suku bunga.

Riset terbaru seperti 
Naifar (2016) menggunakan pendekatan quantile regression untuk menyelidiki comovementdan struktur dependensi antara return Indeks Pasar Syariah Dow Jones,kondisi pasar keuangan global, indikator makroekonomi dan faktor risiko. Dia menunjukkan bahwa imbal hasil indeks pasar saham konvensional, volatilitas pasar saham dan kurva imbal hasil obligasi negara signifikan untuk semua quantiles. Faktor risiko kredit obligasi negara juga memiliki efek yang signifikan selama dan setelah krisis keuangan global. Selain itu, dampak dari harga minyak dan sentimen investor signifikan hanya untuk quantiles yang rendah.

Merujuk pada tinjauan atas literature penelitian sebelumnya seperti yang telah dibahas di atas, penelitian ini mengamati dan menguji perilakuregimeswitchingindeks harga saham syariah agar diketahui secara lebih tajam apakah terdapat perilaku yang berbeda dari indeks konvensional, baik pada rezim atau periode dengan volatilitas imbal hasil yang tinggi maupun pada periode volatilitas yang rendah. Dengan menggunakan regimeswitching regression, kita dapat menguji dampak dari beberapa faktor ekonomi terhadap indeks pasar saham syariah dan indeks pasar saham konvensional, hubungan antara indeks pasar saham syariah dan indeks pasar konvensional dan sekaligus menguji pula apakah semua hubungan tersebut memiliki perbedaan yang signifikan antara rezim volatilitas tinggi dan rezim volatilitas rendah. Penelitian ini memberikan kontribusi penelitian pada analisisperbedaaanantar rezim volatilitas mengingat sebagian besar studi empiris saat ini meneliti hubungan antara indeks saham syariah dan konvensional serta dampak variabel-variabel makroekonomi dengan menggunakan model linear, baik dengan metode OLS maupun dengan uji cointegration, yang tidak dapat mengungkapkan secara lebih tajam perbedaan semua hubungan tersebut pada periode-periode dengan tingkat volatilitas harga yang berbeda.

\section{METODOLOGI DATA}

Data indeks harian IHSG dan Jakarta Islamic Index (JII) diperoleh dari Thomson Reuters untuk 
periode Maret 2013 sampai Maret 2017 yaitu sebanyak 936 hari perdagangan bursa. Data suku bunga pinjaman antar bank harian digunakan data overnight Jakarta Interbank Offered Rate (JIBOR). Nilai tukar rupiah-dollar Amerika serikat digunakan data Jakarta Interbank Spot Dollar (JISDOR). Pemilihan JIBOR dan JISDOR sebagai ukuran atas variabel suku bunga pasar dan nilai tukar memiliki keunggulan tersendiri yaitu pengaruh premi-premi risiko lain seperti premi likuiditas pasar dan premi risiko default serta biaya transaksi dapat diminimalisir bahkan dihilangkan karena JIBOR dan JISDOR adalah output transaksi jangka sangat pendek yang dilakukan antar bank. Data harian JISDOR dan JIBOR diperoleh dari website Bank Indonesia.

\section{Model dan Uji Empiris}

Untuk hubungan antara hasil indeks pasar saham syariah dengan variabelvariabel makroekonomi serta hubungan imbal hasil indeks pasar saham syariah dengan imbal hasil pasar saham konvensional dan volatilitasnya, pertama kali modelregresilinier (persamaan 1) diestimasi dengan metode estimasi OLS. Untuk menguji apakah model regresi linier dapat mendeskripsikan semua hubungan yang ingin diuji, parameter stability test dengan menggunakan uji cumulative sum of squares of recursive residuals (CUSUMSQ) seperti yang diformulasikan oleh Brown, Durbin, and Evans(1975) dilakukan untuk dapat dipastikan memadai atau tidaknya penggunaan model regresi linier OLS untuk menguji hipotesis penelitian sebagai berikut:

RJII $_{t}=a+\beta_{1}$ RIHSG $_{t}+B_{2}$ Var RIHSG $_{t}+B_{3} J I S D O R_{t}+B_{4} I_{I B O R_{t}}+$ $E_{t}(1)$

Dimana RJII adalah imbal hasil harian dari Jakarta Islamic Index, RIHSG adalah imbal hasil harian IHSG, VarRIHSG adalah volatilitas dari imbal hasil harian IHSG, DJISDOR adalah perubahan nilai tukar harian rupiah-dollar Amerika Serikat antar bank, DJIBOR adalah perubahan harian suku bunga pinjaman antar bank.

Untuk menguji stasioneritas semua variabel diuji dengan menggunakan Augmented Dickey-Fuller (ADF) test dengan drift dan trend. Seluruh variabel bersifat stasioner 
dimana hipotesis nol adanya unit root dapat ditolak.

Volatilitas imbal

hasil IHSG diestimasi dengan menggunakan Conditional variance model AR $(P)$ GARCH $(1,1)$ sebagai berikut:

RIHSG $_{t}=a_{0}+\sum_{S=1}^{P} a_{s}$ RIHSG $_{t-}+\varepsilon_{t} ;$ $\varepsilon_{t} \mid \Phi_{t-1} \sim N\left(0, h_{t}\right)$

$h_{t}=\omega_{0}+a \varepsilon^{2}{ }_{t-1}+\beta h_{t}$

Dimana RIHSG adalah imbal hasil harian IHSG, adalah conditional variance dari IHSG, adalah residual dari mean equation yang terdistribusi secara normal dengan rata-rata nol dan varians yang berubah antar waktu..

Hasil estimasi besarnya varians IHSG dengan menggunakan model (3) di atas menjadi variabel independen pada model (1) yang diestimasi dengan metode Ordinary Least Square (OLS) . Model (1) adalah model regresi linier yang mengasumsikan hubungan antara dependent variabel (RJII atau imbal hasil Jakarta Islamic Index) dengan seluruh variabel indpenden bersifat konstan antar waktu, baik pada periode volatilitas yang tinggi maupun pada periode dengan volatilitas yang rendah. Untuk menguji asumsi tersebut, kita dapat menggunakan

parameter stability test yang dapat menunjukkan bahwa terdapat perbedaan parameter yang signifikan antar kedua periode dengan tingkat volatilitas yang berbeda tersebut. Parameter stability test yang dapat digunakan dalam hal ini adalah CUSUM Square Test yaitu cumulative sum of squared recursive residual (Hamilton, 2015). Apabila CUSUM Square Test menunjukkan adanya perbedaan besaran parameter antar periode maka kita dapat menggunakan Markov Regime Switching Regression yang akan mengeluarkan hasil estimasi model regresi secara terpisah untuk periode dengan volatilitas tinggi dan volatilitas rendah. Markov

regression

memungkinkan variabel

mengalami tergantung pada kondisi tertentu (state-dependent) seperti yang ada pada model (4):

$R J I I_{t}=a+\beta_{1, S t} R I H S G_{t}+\beta_{2, S t} I H S G R V_{t}$ $+\beta_{3, S t} J I S D O R_{t}+\beta_{4, S t} J I B O R_{t}+e_{t, S t}$

(4)

Semua parameter regresi pada model (4), , dapat berubah antar waktu mengikuti suatu 
probabilitas transisi tertentu sehingga memiliki besaran yang berbeda tergantung pada regime dimana semua hubungan antar variabel tersebut diamati pada titik waktu tertentu. Regime atau 'state' pada titik waktu ke $\mathrm{t}$ ditulis sebagai. Transisi dari sebuah regime ke regime yang lain diasumsikan mengikuti suatu unobservable Markovchain.

$$
\text { Regresi }
$$

Markov

Regime-Switching pertama kali diformulasikan oleh Goldfeld dan Quandt (1973). Formulasi yang digunakan pada penelitian ini adalah formulasi yang dikembangkan oleh Hamilton (1994) dimana adalah sebuah variabel yang unobservable yang bergerak mengikuti sebuah proses Markov orde pertama. Pada penelitian ini diasumsikan ada dua regime sehingga adalah dua 'state' proses Markov dengan matriks probabilita sebagai berikut:

$\mathrm{P}=\left[\begin{array}{ll}\mathrm{P}_{11} & \mathrm{P}_{21} \\ \mathrm{P}_{12} & \mathrm{P}_{22}\end{array}\right]$

Dimana adalah probabilitas regime no 1 yaitu kondisi volatilitas tinggi yang telah terjadipada periode sebelumnya untuk tetap berada pada regime no 1 pada satu period kemudian. adalah probabilitas regime no 1 yaitu kondisi volatilitas tinggi yang telah terjadi pada periode sebelumnya untuk berubah menjadi berada pada regime no 2 yaitu kondisi volatilitas rendah pada satu periode kemudian. Markov Regime Switching regression diestimasi dengan menggunakan sebuah prosedur maximum likelihood.

\section{PEMBAHASAN}

Tabel 1 memuat statistik deskriptif dari seluruh variabel yang digunakan dalam model penelitian. Imbal hasil indeks saham syariah (JII) sedikit lebih rendah dibandingkan indeks saham konvensional (IHSG). Volatilitas indeks saham syariah sedikit lebih tinggi dibandingkan indeks saham konvensional. JarqueBera test menunjukkan hipotesis bahwa variabel terdistribusi secara normal dapat ditolak untuk semua series variabel, atau dengan kata lain, seluruh variabel tidak terdistribusi normal. Augmented Dickey-Fuller test yang digunakan untuk menguji stasioneritas variabel time series menunjukkan hasil uji yang signifikan sehingga dapat dinyatakan bahwa seluruh variabel stasioner. 
Tabel 1. Statistik Deskriptif

\begin{tabular}{lccccc}
\hline & RIHSG & RJII & $\begin{array}{c}\text { DJIS- } \\
\text { DOR }\end{array}$ & DJIBOR & VarIHSG \\
\hline Mean & 0.003401 & 0.003384 & 3.840689 & $1.90 \mathrm{E}-05$ & 0.002453 \\
Median & 0.000881 & 0.000713 & 6.000000 & $-1.90 \mathrm{E}-05$ & 0.001508 \\
Maximum & 2.005176 & 2.006523 & 301.0000 & 1.000000 & 0.630300 \\
Minimum & -0.055844 & -0.063899 & -317.0000 & -1.998127 & $3.22 \mathrm{E}-05$ \\
Std. Dev. & 0.074316 & 0.074878 & 63.65490 & 0.081615 & 0.021993 \\
Skewness & 23.70854 & 23.23096 & -0.451635 & -11.85426 & 26.35135 \\
Kurtosis & 603.5028 & 587.2868 & 6.566381 & 436.1877 & 729.8663 \\
& & & & & \\
Jarque-Bera & 14045398 & 13298240 & 523.9161 & 7285437. & 20558470 \\
Probability & 0.000000 & 0.000000 & 0.000000 & 0.000000 & 0.000000 \\
Observations & 929 & 929 & 929 & 929 & 929 \\
\hline
\end{tabular}

Hasil estimasi besarnya signifikan baik pada conditional variance dari imbal konstanta $\mathrm{C}, \mathrm{ARCH}(-1)$ atau hasil IHSG, sebagai salah squared residual satu periode satu variabel independen sebelumnya, maupun pada yang ada pada model (1) GARCH (-1) yaitu conditional dapat dilihat pada Tabel 2. variance pada satu periode Mean Equation berisi dua sebelumnya. Secara lengkap variabel autoregressive (AR), model conditional variance berdasarkan indikasi melalui imbal hasil IHSG dapat ditulis correlogram, yaitu lagged 5 sebagai berikut: dan lagged 1 period. Variance $\mathbf{Y}_{t}=\mathbf{0 , 0 0 7 5} \mathbf{Y}_{t-5}+\mathbf{0 , 3 1 1} \mathbf{Y}_{t-1} \mathbf{e}_{t}$

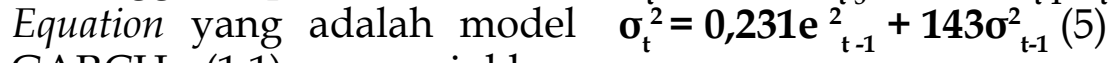
GARCH $(1,1)$ menunjukkan 


\section{Tabel 2. Hasil Estimasi}

\begin{tabular}{|c|c|c|c|c|}
\hline Variabel & Koefiisien & Std. Error & z-Statistic & Prob. \\
\hline $\operatorname{AR}(5)$ & -0.00757 & 0.090875 & -0.08324 & 0.9337 \\
\hline \multirow[t]{2}{*}{$\operatorname{AR}(1)$} & 0.311893 & 0.037937 & 8.221423 & 0,0000 \\
\hline & Variance Equat & ion & & \\
\hline $\mathrm{C}$ & 0.001717 & $1.54 \mathrm{E}-05$ & 111.5934 & 0,0000 \\
\hline $\operatorname{ARCH}(-1)$ & 0.231368 & 0.042966 & 5.384863 & 0,0000 \\
\hline GARCH(-1) & 0.143 & 0.009434 & -15.1587 & 0,0000 \\
\hline R-squared & 0.14937 & & & \\
\hline Adjusted R-squared & 0.148453 & & & \\
\hline Log likelihood & 1778.285 & & & \\
\hline Durbin-Watson stat & 1.710562 & & & \\
\hline
\end{tabular}

\section{Conditional Variance IHSG}

Besarnya conditional variance imbal hasil harian IHSG diperoleh dengan mendasarkan pada model conditional variance di atas melalui proses forecasting dengan menggunakan software ekonometrika EViews. Pada Tabel 1 dapat dilihat statistik deskriptif varians dari imbal hasil IHSG. Rata-rata conditional variance imbal hasil harian IHSG pada periodeyang diobservasi adalah sebesar $0,245 \%$ dan median sebesar $0,15 \%$. Perbedaan antara mean dan median yang cukup besar ini mengindikasikan adanya nilai ekstrim conditional variance IHSG yang cukup besar sekaligus menunjukkan adanya perbedaan varians yang cukup besar antar periode.

\section{Tabel 3. Hasil Estimasi Model dengan OLS}

\begin{tabular}{lll}
\hline \multicolumn{1}{c}{ Variabel } & \multicolumn{1}{c}{ Koefisien } & \multicolumn{1}{c}{ t-Statistic } \\
C & $-0.00031^{*}$ & -1.79273 \\
RIHSG & $0.948843^{* * *}$ & 73.44697 \\
Var RIHSG & $0.201464^{* * *}$ & 4.355192 \\
DJISDOR & $-7.13 \mathrm{E}-06^{* *}$ & -2.85276 \\
DJIBOR & $0.063333^{* * *}$ & 4.46635 \\
R-squared & 0.995863 & \\
Adjusted R-squared & 0.995845 & \\
Log likelihood & 3639.248 & \\
F-statistic & 55605.4 & \\
Prob(F-statistic) & 0,0000 & \\
\hline
\end{tabular}


Hasil estimasi model regresi linier dengan metode estimasi OLS dapat dilihat pada Tabel 3. Seluruh variabel independen signifikan secara statistik. Namun apabila kita lakukan parameter stability test atas seluruh koefisien hasil estimasi dengan menggunakan metode OLS, dapat kita nyatakan bahwa model regresi linier dengan OLS tersebut tidak memadai karena terdapat perbedaan yang sangat signifikan besarnya koefisien dari seluruh variabel indpenden pada dua kondisi yang berbeda yaitu pada periode dengan volatilitas imbal hasil yang tinggi denganperiode dimana volatilitas imbal hasil cukup rendah. Indikasi parameter yang tidak stabil ini dapat dilihat pada hasil Uji CUSUM Square seperti yang dapat dilihat pada Gambar 1 .
Garis solid terlihat melewati batas atas dan batas bawah signifikansi 5\% sehingga dapat kita nyatakan bahwa parameter hasil estimasi dengan menggunakan metode OLS menghasilkan parameter/koefisien regresi yang tidak stabil atau berbeda signifikan antara dua periode volatilitas tersebut sehingga kita membutuhkan model yang dapat menunjukkan perbedaan besarnya semua koefisien regresi antara periode dengan volatilitas tinggi dengan periode dengan volatilitas rendah. Model yang dapat mengungkapkan hal itu adalah Model regresi Markov Regime-Switching seperti yang telah dijelaskan pada bagian Metode Penelitian sebelum ini.

Hasil estimasi model regresi Markov-Regime Switching dapat dilihat pada

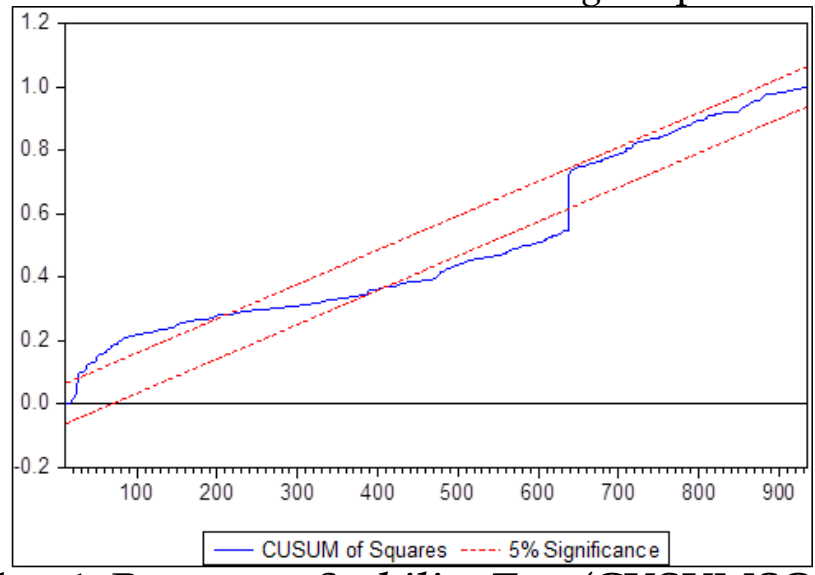

Gambar 1. Parameter Stability Test (CUSUMSQ Test) 
Tabel 4 yang menunjukkan perbedaan hasil estimasi koefisien regresi antara dua regime volatilitas imbal hasil. Imbal hasil indeks saham konvensional (IHSG) terbukti signifikan mempengaruhi imbal hasil indeks syariah (Jakarta Islamic Index), baik pada regime volatilitas tinggi maupun regime volatilitas rendah. Namun besarnya koefisien imbal hasil IHSG pada regime volatilitas rendah lebih besar dibandingkan dengan pada regime volatilitas tinggi. Temuan ini sejalan dengan temuan para peneliti sebelumnya seperti Naifar (2016) dan Albaity dan Ahmad (2008) yang menunjukkan bahwa imbal hasil indeks syariah berhubungan erat dengan imbal hasil indeks saham konvensional. Terdapat comovement atau pergerakan bersama antara imbal hasil indeks saham konvensional dan imbal hasil indeks syariah. Adanya comovement ini menunjukkan saham-saham yang masuk dalam indeks saham syariah memiliki hubungan yang erat serta dipengaruhi pergerakannya oleh imbal hasil saham konvensional. Adanya comovement atau pergerakan imbal hasil indeks syariah yang disebabkan oleh pergerakan imbal hasil indeks konvensional satu periode sebelumnyajugamenunjukkan bahwa indeks saham konvensional mencerminkan sentiment dan penilaian para investor terhadap kondisi makroekonomi secara umum. Perubahan sentiment investor ini lah yang menggerakkan perubahan imbal hasil sahamsaham yang ada di indeks syariah.

Volatilitas imbal hasil indeks saham konvensional terbukti signifikan mempengaruhi imbal hasil indeks saham syariah, baik pada regime volatilitas imbal hasil rendah maupun tinggi. Dengan menggunakan conditional variance GARCH $(1,1)$, volatilitas imbal hasil indeks konvensional lebih tinggi $(0,188)$ dan lebih tinggi tingkat signifikansinya (level of error $=1 \%$ ) pada regime volatilitas imbal hasil yang tinggi dibandingkan dengan regime volatilitas yang rendah $(0,134$ dan level of error $=5 \%)$. Temuan ini menunjukkan bahwa pada saat regime volatilitas yang tinggi, imbal hasil indeks saham syariah jauh lebih kuat dipengaruhi oleh varians imbal hasil indeks saham konvensional yang mencerminkan tingkat ketidakpastian sentiment 
investor dan ketidakstabilan strategi investasinya, namun penilaian investor terhadap pada saat turbulensi pasar prospek makroekonomi. saham yang sedang tinggi,

Tabel 4. Hasil Estimasi Markov-Regime Switching Regression

\begin{tabular}{lll}
\hline Variabel & Koefisien & Z statistic \\
\hline \multicolumn{3}{c}{ Regime 1 (Volatilitas Tinggi) } \\
C & $-0.0011^{* * *}$ & -2.86281 \\
RIHSG & $0.950285^{* * *}$ & 42.77017 \\
Var IHSG & $0.188898^{* *}$ & 2.326837 \\
DJISDOR & $-7.62 \mathrm{E}-06$ & -1.56453 \\
DJIBOR & $0.057094^{* *}$ & 2.327991
\end{tabular}

\begin{tabular}{lll} 
Regime 2 (Volatilitas Rendah) & \\
C & 0.000144 & 0.495239 \\
RIHSG & $1.319035^{\star * *}$ & 31.02359 \\
Var IHSG & $0.134927^{\star}$ & 1.925798 \\
DJISDOR & $7.85 \mathrm{E}-06^{\star *}$ & 2.213637 \\
DJIBOR & $0.043075^{\star *}$ & 1.978711 \\
\hline
\end{tabular}

Pada volatilitas yang perubahan nilai tukar tidak tinggi perubahan nilai tukar lagi menjadi faktor penting (DJISDOR) tidak signifikan bagi sebagian besar investor mempengaruhi imbal hasil yang tetap aktif bertransaksi indeks saham syariah. pada kondisi turbulensi Sebaliknya pada saat regime tersebut. Tidak signfikannya volatilitas rendah, perubahan perubahan nilai tukar pada nilai tukar terbukti signifikan. saat volatilitas imbal hasil yang Temuan ini menarik dalam tinggi dapat disebabkan oleh konteks pasarsaham Indonesia dua kemungkinan. Pertama, yang pergerakannya sangat investor yang terlibat aktif dipengaruhi posisi investasi bertransaksi pada saat pasar para investor asing di pasar. turbulens adalah para investor Investor asing pasti sangat yang tergolong sebagai dipengaruhi oleh perubahan spekulator dan didominasi nilai tukar dalam memutukan oleh para investor domestik. 
Investor asing lebih banyak yang tergolong sebagai strategic investor yang lebih memperhatikan fundamental perusahaan dan prospek jangka panjang dari pada spekulasi naik-turunnya harga jangka pendek (Dvorak, 2005). Kedua, pada saat pasar sedang turbulens biasanya kondisi makroekonomi juga sedang tidak pasti sehingga nilai tukar sulit untuk digunakan sebagai dasar strategi investasi jangka pendek. Uji empirik atas dua kemungkinan di atas menjadi tantangan dan isu bagi penelitian selanjutnya.

Perubahan tingkat suku bunga pasar (DJIBOR) terbukti signifikan pada regime volatilitas tinggi maupun rendah. Temuan di pasar saham Indonesia ini berbeda dengan yang ditemukan oleh Mohammad Yusof dan Abdul Majid (2007) di pasar saham Malaysia. Shamsuddin (2014) juga membuktikan Indeks pasar saham syariah Dow Jones tidak dipengaruhi suku bunga. Namun Shamsuddin (2014) menemukan di beberapa sektor industri beberapa portofolio ekuitas Islam menunjukkan korelasi yang cukup tinggi dan signifikan dengan perubahan tingkat bunga. Tingkat suku bunga menjadi variabel penting saat menentukan strategi investasi di pasar saham, termasuk investasi di saham-saham yang masuk di dalam indeks syariah. Suku bunga menjadi patokan keputusan investasi di pasar saham atau di pasar obligasi dan deposito yang menjanjikan pendapatan bunga yang jauh lebih pasti, baik pada kondisi volatilitas tinggi maupun rendah. Koefisien DJIBOR sedikit lebih tinggi pada regime volatilitas imbal hasil yang tinggi yang menunjukkan

perubahan suku bunga sedikit lebih tinggi pada saat volatilitas tinggi.

Namun apabila dilihat sisi yang lain, signifikannya pengaruh suku bunga pasar terhadap imbal hasil indeks syariah memunculkan kecurigaan bahwa sahamsaham yang masuk dalam indeks syariah belum sepenuhnya shariah compliance dalam arti komponen pendapatan perusahaan maupun biaya perusahaan masih cukup besar berkaitan dengan suku bunga. Penyusunan indeks syariah memang belum mensyaratkan perusahaan yang sahamnya dimasukkan kedalam indeks syariah sepenuhnya bebas dari transaksi ribawi yang berkenaan dengan bunga. 
Apabila indeks syariah hanya berisi saham-saham yang bersih sama sekali dari transaksi melibatkan suku bunga tentu sudah seharusnya pengaruh suku bunga terhadap perubahan indeks syariah tidak signifikan (Umar (2017).

S i g n if i k a n n y a hubungan antara suku bunga dan imbal hasil indeks pasar syariah membuka pertanyaan lanjutan untuk riset selanjutnya yaitu apakah pengelompokan saham syariah yang diputuskan oleh otoritas pasar modal sebagai saham-saham yang masuk di dalam Jakarta Islamic Index sudah cukup ketat sehingga saham-saham dari perusahaan yang memiliki transaksi yang melibatkan suku bunga cukup besar sudah dieliminasi dari indeks tersebut? Oleh karena jika komponen biaya bunga sudah tidak signifikan, pergerakan harga saham perusahaan yang termasuk di dalam indeks syariah seharusnya tidak terlampau dipengaruhi lagi oleh pergerakan suku bunga pasar. Hal ini lah yang ditemukan antara lain oleh Umar (2017), el Alaoui (2014) dan Mohammad. Yusof dan Abdul Majid (2007). Namun signifikannya hubungan antara indeks pasar saham syariah dengan suku bunga dapat juga disebabkan oleh kondisi spesifik mikrostruktur pasar saham Indonesia dimana peran dan proporsi dana investor asing yang cukup besar dalam menggerakkan pasar saham. Dana investor asing yang masuk ke pasar saham, termasuk di dalamnya sahamsaham yang digolongkan sebagai saham sesuai syariah, sangat dipengaruhi oleh perubahan tingkat suku bunga pasar karena investor asing mengalokasikan dananya secara bersamaan di pasar obligasi pemerintah dan korporasi yang imbal hasilnya sangat dipengaruhi pergerakan suku bunga. Aliran dana investor asing ke pasar saham dari pasar obligasi atau sebaliknya keluar dari pasar saham ke pasar obligasi sangat dipengaruhi oleh perubahan suku bunga pasar. Apakah capital flight antar pasar keuangan yang dilakukan oleh investor asing telah menyebabkan adanya hubungan positif signifikan antara imbal hasil pasar saham syariah di Indonesia dengan suku bunga menjadi pertanyaan penelitian lanjutan dari riset ini.

Umar

menawarkan argument lain 
atas signifikannya pengaruh variabel makroekonomi seperti nilai tukar dan suku bunga terhadap pergerakan indeks saham syariah yaitu adanya alokasi investasi yang berbeda antara investor jangka panjang dan investor yang bertransaksi dengan menggunakan horizon investasi yang jauh lebih pendek. Investor jangka panjang diasumsikan lebih memilih saham-saham yang memiliki prospek usaha jangka panjang yang stabil yang umumnya saham-saham syariah termasuk di dalamnya. Sementara investor jangka pendek, karena keputusan investasinya hanya didorong oleh perubahan posisi jangka pendek harga saham, lebih memilih saham-saham yang bergerak secara volatile dalam jangka pendek. Ketika rezim volatilitas suku bunga tinggi dan nilai tukar yang tinggi pula yang menjadi ciri dari kondisi makro yang sedang kurang stabil, sebagian investor jangka pendek mengalihkan alokasi investasinya ke sahamsaham yang lebih aman dalam jangka panjang. Hal ini lah yang menyebabkan adanya perbedaan hubungan yang signfikan pada kedua rezim seperti yang dapat dilihat pada hasil penelitian di atas.

\section{SIMPULAN}

Imbal hasil indeks syariah di Bursa Efek Indonesia memiliki hubungan positif yang signifikan dengan imbal hasil indeks konvensional dan volatilitasnya,baikpadaregime volatilitas tinggi maupun yang rendah.Comovement antara indeks syariah dengan indeks pasar saham konvensional mengindikasikan adanya hubungan kointegrasi antara kedua pasar tersebut. Comovement antara indeks syariah dan indeks pasar konvensional jauh lebih kuat pada saat volatilitas rendah dibandingkan pada regime volatilitas yang tinggi. Patut diduga pada saat volatilitas tinggi, pergerakan indeks pasar saham dipengaruhi lebih banyak faktor, baik faktor ekonomi maupun faktor-faktor non ekonomi seperti sentimen investor dan spekulasi investor jangka pendek, yang berbeda pengaruhnya secara cukup signifikan terhadap indeks syariah.

\begin{tabular}{|c|c|}
\hline Variabel & makr \\
\hline ekonomi yang & signfil \\
\hline mempengaruhi & \\
\hline $\begin{array}{l}\text { indeks sahar } \\
\text { ah suku bun }\end{array}$ & sya \\
\hline $\begin{array}{l}\text { lalah suku bun } \\
\text { gnifikannya }\end{array}$ & \\
\hline snifikannya & \\
\hline
\end{tabular}


syariah di Bursa Efek Indonesia dengan perubahan suku bunga memunculkan pertanyaan apakah saham-saham perusahaan yang termasuk di dalam Jakarta Islamic Index telah disaring secara ketat sehingga komponen biaya bunga sudah minimal. Apabila saham yang termasuk di dalam Jakarta Islamic Index sudah cukup ketat restriksinya dari sudut syariah, kemungkinan mikro struktur pasar saham Indonesia yang didominasi investor asing yang menyebabkan hubungan yang signfikan tersebut.

Model regresi Markov regime-Switching mampu mengungkapkan adanya perbedaan yang sangat besar dari pengaruh perubahan nilai tukar terhadap imbal hasil indeks syariah antara regime volatilitas yang tinggi dengan regime volatilitas yang rendah. Pengaruh nilai tukar hanya signifikan pada saat regime volatilitas yang rendah. Hal ini tidak dapat diungkap jika kita hanya menggunakan model regresi linier OLS biasa. 


\section{Daftar Pustaka}

Abdul Majid, M. S., \& Mohamad Yusof, R. (2009). Longrun relationship between Islamic stock returns and macroeconomic variabels: An application of the autoregressive distributed lag model. Humanomics, 25, 127-141.

Ajmi, A. N., Hammoudeh, S., Nguyen, D., \& Sarafrazi, S. (2014). How strong are the causal relationships between Islamic stock markets and conventional financial systems? Evidence from linear and nonlinear tests. Journal of International Financial Markets, Institutions \& Money, $28,213-227$.

Albaity, A., \& Ahmad, R. (2008). Performance of Syariah and composite indices: Evidence from bursa Malaysia. Asian Academy of Management Journal of Accounting and Finance, 4, 23-43.

Albaity, M. S. (2011). Impact of the monetary policy instruments on Islamic stock market index return. Economics Discussion Papers, No 2011-26. Kiel Institute for the World Economy.

Brown, R. L., Durbin, J., \& Evans, J. M. (1975). Techniques for testing the constancy of regression relations over time. Journal of the Royal Statistical Society, 37, 149-192.

Chen, N. F., Roll, R., \& Ross, S. A. (1986). Economic forces and the stock market. Journal of Business, 59, 383e403.

Choudhry, T. (2001). Inflation and rates of return on stock: Evidence from highinflation countries. Journal of International Financial Markets, Institutionsand Money, 11, 75-96.

Dewandaru, G, Rizvi, SA, Masih, R, Masih, M, \& Alhabshi,SA, (2014) Stock market co-movements: Islamic versus conventional equity indices with multi-timescales 
analysis Economic Systems 38 (4), 2014, 553-571.

Dvorak, T, 2005. Do Domestic Investors Have an Information Advantage? Evidence from Indonesia, The Journal of Finance, 60(2), 817-839.

el Alaouia, A.K,Bachaa, O.I, Masiha, M.,Asutay,M.(2016)Shari'ah screening, market risk and contagion: A multi-country analysis Journal of Economic Behavior \& Organization, 132, 2016, Pages 93-112.

Fama, E. (1981). Stock returns, real activity, inflation, and money. AmericanEconomic Review, 71, 545-565.

Geske, R., \& Roll, R. (1983). The fiscal and monetary linkage between stockreturns and inflation. The Journal of Finance, XXXVIII, 1-33.

Hondroyiannis, G., \& Papapetrou, E. (2006). Stock returns and inflation inGreece: A Markov switching approach. Review of Financial Studies, 15,76-94.

Hussin, M. Y. M., Muhammad, F., Abu Hussin, M. F., \& Abdul Razak, A.(2012). The relationship between oil price, exchange rate and Islamic stock market in Malaysia. Research Journal of Finance and Accounting, 3, 22222847.

Mohamad Yusof, R., \& Abdul Majid, M. S. (2009). Stock market volatility transmission in Malaysia: Islamic versus conventional stock market. Journal of King Abdulaziz University: Islamic Economics, 20, 17-35.

Naifar, N. (2016). Do global risk factors and macroeconomic conditions affect global Islamic index dynamics? A quantile regression approach. The Quarterly Review of Economics and Finance, 61, 29-39.

Rigobon, R., \& Sack, B. (2004). The impact of monetary policy on asset prices. Journal of Monetary Economics, 51, 1553-1575. 
Sakti, M. R.P, \& Harun, M. D. Y. (2013). Relationship between Islamic stock prices and macroeconomic variabels: Evidence from Jakarta stock exchange Islamic index. Global Review of Islamic Economics and Business, 1, 7184.

Shamsuddin, A. (2014). Are Dow Jones Islamic equity indices exposed to interest rate risk? Economic Modelling, 39, 273-281.

Shiller, S., \& Beltratti, A. (1992). Stock prices and bond yields: Can their comovements be explained in terms of present value models? Journal of Monetary Economics, 30, 25-44.

Umar, Z (2017), Islamic vs conventional equities in a strategic asset allocation framework, Pacific-Basin Finance Journal, $42,1-10$ 